1981-01-01

\title{
Some Problems with Marx's Theory of Capitalist Penetration into Agriculture: the Case of Ireland
}

\author{
Ellen Hazelkorn \\ Technological University Dublin, ellen.hazelkorn@tudublin.ie
}

Follow this and additional works at: https://arrow.tudublin.ie/cserart

Part of the Comparative Politics Commons, and the Political Theory Commons

\section{Recommended Citation \\ Hazelkorn, E. (1981). Some Problems with Marx's Theory of Capitalist Penetration into Agriculture: the Case of Ireland.Economy and Society, Volume 10,no. 3, doi:10.1080/03085148100000015}

This Article is brought to you for free and open access by the Centre for Social and Educational Research at ARROW@TU Dublin. It has been accepted for inclusion in Articles by an authorized administrator of ARROW@TU Dublin. For more information, please contact arrow.admin@tudublin.ie, aisling.coyne@tudublin.ie, gerard.connolly@tudublin.ie.

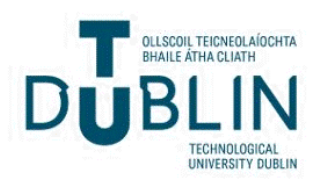


Some Problems with Marx's Theory of Capitalist Penetration into Agriculture: The Case of Ireland

Ellen Hazelkorn

College of Commerce

Dublin Institute of Technology

Dublin 6

December 1980 


\section{In ${ }^{1}$ 1855, Kar 1 Marx, surveying developments in Ireland}

after the Great Famine of 1845-1849, argued that Irish agriculture was proceeding along a path of growth similar to the British experience more than a century earlier. ${ }^{2}$ In the course of the post-famine readjustment, "the Irish agricultural system," he wrote, "is being replaced by the English system, the system of small tenures by big tenures, and the modern capitalist is taking the place of the old landowner ${ }^{3}$ Further, with reference to the dramatic decine in the number of landholdings under 15 acres, he argued that centralisation of land was occurring at a "rapid rate." As evidenced in England, holdings between 15 and 100 acres, "too small for capitalist cultivation," would likewise disappear. Sheep and cattle would soon replace the Irish peasant, as had occurred on the Scottish Highlands, and thus, finally secure the country's position as an agricultural region of industrialised England. 4 Implicit in Marx's argument was the belief that capitalist expansion, initially into agriculture, would result in the inevitable contradiction between capital and labour, and hence a social revolution.

Thirty years after Marx called attention to the expansion

1.

2 .

3. Karl Marx, "Ireland's Revenge," Neue Oder-Zeitung, March 16,

4. Marx, Capita1, 1:711. See further Karl Marx, "Notes for an

This paper is a revised draft of a paper read before the Socialist Studies Seminar, University of Kent, March 1979. Cf. Karl Marx to the Editorial Board of the otechestvenniye Zapiski, November 1877; Karl Marx to Vera Zasulich, March 8, 1881; Karl Marx, Capital (New York, 1967) 1:716. 1855, in R. Dixon, ed., Ireland and the Irish Question. A Collection of Writings by Karl Marx and Frederick Engels, prepared by Lo I。 Golman and V. E。 Kunina (New York, 1972;
henceforth MEI) P。76。 Undelivered Speech on Ireland," November 26, 1867, and "outline of a Report on the Irish Question to the Communist Edum cational Association of German Workers in London," December 16, 1867, MEI: 120-139. In addition, see Karl Marx, "Elections/ Financial Clouds/The Duchess of Sutherland and Slavery," New York Daily Tribune (henceforth NYDT), February 9, 1853, MEI:53; "Forced Emigration/Kossuth and Mazzini/The Refugee Question/Election Bribery in England/Mr. Cobden," NYDT, March 22, 1853, MEI:54-58; "Attack at Sevastopol/The Clearing of the Landed Estates of Scot land," NYDT, June 2, 1854. 
of capitalism into Irish agriculture, Frederick Engels in an interview with the New Yorker Volkszeitung suggested that capitalist expansion had slowed considerably. ${ }^{5}$ The process of land centralisation, hastened by the famine, the repeal of the Corn Laws, and the Encumbered Estates Acts of 1849-1853, had slackened, if not reversed. Assessing the potential for social revolution in Ireland, he remarked that the Irish peasant desired only to own land。 How can we account for this discrepancy between Marx and Engels: analyses? Had Marx seriously misread or misinterpreted the events of the 1850 s or had unforseen developments occurred to significantly alter the situation thirty years later? This paper seeks to present some understanding of this divergence in opinion, and to argue that Marx's analysis of capitalist penetration into agriculture, although preceding the agitation of the Land League in the late 1870s, is nevertheless inadequate. Insofar as he assumed an affinity between industrial capitalist growth and agricultural growth, he ignored the political machinations of the rural bourgeoisie and the campaign for peasant proprietorship. The agrarian revolution that Marx witnessed and documented in his writings of the 1850 s and 1860 s was displaced by another, and more dramatic revolution in landownership.

The first part of this paper will briefly outline Marx's aceount of primitive accumulation as it occurred in post-famine Ireland, and provided the material base from which he deduced unhindered capitalist expansion; the second and third sections will raise questions with his thesis, looking not only at the effect of subsequent events but also, and more fundamentally, at his theoretical configuration of capitalist agriculture; while the final section will offer some general comments on the implications that this miscalculation had for Marx and Engels" political premise that a nationalist revolution in Ireland could accelerate a social revolu-

"Interview with Frederick Engels," New Yorker Volkszeitung, no. 226, September 20, 1888, MEI:343. When asked about the likelihood of a socialist revolution in Ireland, Engels replied: "A purely socialist movement cannot be expected in Ireland for a considerable time. People there want first of all to become peasants owning a plot of land, and after they have achieved that, mortgages will appear on the scene and they will be ruined once more。" 
tion in England."

In the chapter on the General Law of Capitalist Accumulation in the first volume of Capital is an often ignored section concerning Ireland. Therein, Marx persuasively argued that Ireland since the Great Famine had been transformed into an agricultural region of industrial England. 7 The mechanism of this transition, following quite naturally upon the heels of the famine - albeit, significantIy accelerated by the repeal of the Corn Laws and the Encumbered Estates Acts - rested with the fundamental economic equation of the relation between the agricultural and industrial sectors within an integrated, and expanding economy. 8 Moreover, he suggested that without the transference of Irish capital, labour and foodstuffs to England, capitalist accumulation would have been curtailed. Hence, he identified accumulation (and here stands the justification for the inclusion of the Irish section in that volume one chapter) as the main cause of the displacement of the Irish agricultural population, and its degrading poverty. Accumulation, furthermore, provided an explanation for the predominance of the agrarian sector and the general weakness of Irish industry.

6. On this general strategy, see Marx to Ludwig Kugelmann, October 11, 1867; Marx to Engels, November 30, 1867; Marx to Enge1s, November 26, 1867; Marx to Ludwig Kugelmann, November 29, 1869; Marx to Engels, November 10, 1869; Marx to Paul and Laura Lafargue, March 5, 1870; Marx to Ludwig Kugelmann, March 28, 1870; Marx to Sigfrid Meyer and August Vogt, April 9, 1870 .

7. Marx, Capita1, 1:697-712; see also Kar1 Marx, "Indian Question/ Irish Tenant-Right," NYDT, July 11, 1853, MEI:59-65; "Ireland's Revenge;" "The State of British Manufacturing Industry, "NYDT, August 6 and 24, 1860; Marx to Engels, November 30, 1867.

8. Cfo, for example, A. H. John, "Agricultural Productivity and Economic Growth in England, 1700-1760 (with a postscript)," in E. L. Jones, ed., Agriculture and Economic Growth in England, 1650-1815 (London, 1967); Doreen Warriner, Economics of Peasant Farming (London, 1964); John W. Mellor, "Towards a Theory of Agricultural Development," in Hermann M. Southwark and Bruce F. Johnston, eds., Agricultural Development and Economic Growth (Ithaca, 1971); L. M. Cullen, Anglo-Irish Trade (Manchester, 1968); cf. Raymond Crotty, "Capitalist Colonialism and Peripheralisation: the Irish Case, "in Dudley Seers, Bernard Schapper and Marja-Liisa Kiljunen, Under- 
Following the opening of free trade between England and Ireland under the 1801 Act of Union, it was natural that the less competitive industries would succumb, that middlemen and landlords would seek to invest their profits in industry where returns were higher than in agriculture, and that subsequently, Ireland would concentrate on agricultural production for which a ready and expanding English market was available. The agricultural population, set-free from the land, was faced with either starvation or emigration.9 Indeed, Marx went on to suggest that as long as Ireland remained politically tied to England, she would remain economically tied; in contrast, independence would result in a full-scale agrarian revolution (of which English legislation provided only the legal trimmings), and the opportunity for industrial growth under protective tariffs. 10

The famine f $_{1845}$ provided a convenient mechanism through which England intervened in the Irish economy transforming its agrarian economy from a semi-feudal to capitalist mode of production. 11 Already mercantilist restrictions on the movement of capital and labour had come under attack by free-traders in England; legislative initiatives designed to cope with the aftermath of the famine provided an impetus and mechanism easing the sale of indebted. estates by indolent landlords, the consolidation of estates, the eviction of an otherwise concealed surplus population, and the transition from tillage (labour-intensive) to pasture (extensive although not necessarily capital-intensive) agriculture。 Marx argued that

developed Europe: Studies in Core-Periphery Relations (Hassocks, 1979): for a fu11 discussion of Marx and Engels' views on post-famine Irish economic growth, see B. Hazelkorn, "Capital and the Irish Question," Science and Society, vol. $44, \frac{\text { no. } 3}{3}$ (Fal1 1980) pp. 326-356, and Karl Marx and Frederick Engels: The Irish Dimension, $\mathrm{Ph} . \mathrm{D}$.

9. Marx, "Outline Report," MEI:126; Marx, Capita 1, 1:704. Cf. Joseph Lee, The Modernisation of Irish Society, 1848-1918, The Gi11 History of Ireind, vol. 10, J. Lydon and M. MacCurtain, eds. (Dublin, 1973); Cormac ó Gráda, "Demographic Adjustment and Seasonal Migration in 19th Century Ireland," paper prepared for conference of French and Irish Economic Historians, revised draft April 1978.

10. Marx to Engels, November 30, 1867; also Marx to Ludwig Kugelmann, November 29, 1869.

11. Both Marx and Engels argue that the English state played a progressive role in effecting the transition to capitalist agriculture. See, Marx, "In cf. Karl Marx, "British Rule in India," NYDT, June 25, 1853 , in Shlomo Avineri, ed., Karl Marx on Colonialism and Modernisation (New York, 1969) pp. 88-95; Lee, Modernisation, pp. 20- 
while this process was to be welcomed, as through the "progressive concentration of small tenancies" the termination of a "worked-out old system" was brought about, he condemned British endeavours which ruthlessly manipulated the events of the 1840 s in the interests of capital. 12 In sharp contrast to Malthusians and John Bright radicals, Marx argued that if left unchecked British policy sought to transport and transform the Irish peasantry to English industrial cities as proletarians, increasing the number of the existing reserve army of labour. There, their numbers would put pressure on wages received by English workers, fostering competition between the two nationalities, and hence effectively dividing the working class to the benefit of capital. This new colonial policy, differing qualitatively from colonialism under mercantilist capital, was, not surprisingly, welcomed by both the aristocracy and the bourgeoisie. 13

In Ireland, centralisation of land and concentration of ownership proceded at a "rapid rate." Citing figures for landownership for the years 1851 to 1861, and for profits received in 1864 and 1865 , Marx argued that an agricultural revolution was underway, the first act of which was to "sweep away" the huts of the cottier and the small tenant. 14 Land centralisation was not, however, a policy superimposed upon a quiescent Ireland by England, but coincided with the birth of an Irish rural bourgeoisie. The introduction of free trade through the Encumbered Estates Acts had induced the absentee landlords to sell out to men "who wanted to run their farms on modern economic lines."15 These new landowners, "mainly Irish Catholics," did not, despite the rise in the number of land sales after 1849, lead to a proliferation in the number of owners. That figure remained relatively stagnant, supporting Marx's contention in Capital that the post-famine period provided an opportunity for landowners andflarge tenant-farmers to augment their existing holdings.

35: and Peter Gibbon, "Colonialism and the Great Starvation in Ireland, 1845-9," Race and Class, vol. 17, no. 2 (1975) pp. 131-139. 12. Marx, "Indian Question/Irish Tenant-Right;" Marx, Capital,
1:703-704.

13. Marx to Sigfrid Meyer and August Vogt, April 9, 1870.

14. Marx, Capita1, 1:703-712.

15. Marx to Enge1s, Apri1 14, 1870; Engels to Marx, Apri1 15, 1870; Marx, "Out line Report," MEI: 135; Engels to Marx, January' 13, 1870. 
Although still far from the English level of centralisation, Marx proposed that Ireland would follow a path to capitalism similar to that in England. He outlined one path in which the landlord class separated the direct producers from the soil (forcibly if necessary by mears of eviction and expropriation) and replaced them directly or in stages ("metayage") with the capitalist farmer, who in turn hired wage-labour. 16 The thread of development running through his work was clear; Marx foresaw the "doom of the small peasant, transition from patriarchal to rational exploitation of agriculture, conflicts of interest between landlords and capitalists, industrialisation of agriculture, and the final fusion of the two major exploiting classes. The all-round superiority of large-scale agriculture, its possibilities in getting greater soil fertility and in economizing, etc. . . [was] the basic economic reason for the extinction of the small peasant."17 Marx had stated this view for Ireland as early as 1853 in an article entitled "Forced Emigration". "The modern changes in the art of production have.. broken down the antiquated system of society... they have expropriated the Irish cottier and tenant. . they will expropriate, in due time, the landlord."18 He foresaw no alternative path nor suggested any hesitation in this one. Yet, years later, Engels was forced to qualify Marx's earlier comments. From the vantage point of the 1880s, Engels point out that the land-hungry desires of the Irish tenant-farmer were a stumbling block to capitalist expansion and hence socialist revolution. 19

In attempting to assess the divergence between Marx's earlier view of capitalist growth with Engels' remarks, it is necessary to ask whether events arose to significantly alter the material conditions upon which Marx based his views. Second, could or should he

16. Marx, Capita 1, 1:742-744; 3:802-813.

17. Henry Mayer, "Marx, Engels and the Politics of the Peasantry,"

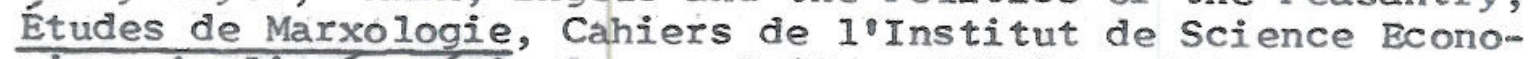
mique Appliqué, série S, no. 3 (June 1960) p. 112; see also Jarius Banaji, "Kautsky's Agrarian Question," Economy and Society, vol. 5, no. I (February 1976) pp. 1-49; Cormac O Grada, "On Some Aspects of Productivity Change in Irish Agriculture, 1845-1926," paper prepared for the 7th International Economic History Conference, 1978, argues that Irish peasant agriculture was probably efficient given the existing conditions.

18. MEI:58.

19. "Interview with Frederick Engels." 
have been aware of these developments when he wrote on Ireland? What were the limitations on his writing?? And third, how appropriate was his view of a singular path to capitalist agriculture for the Irish experience?

Marx wrote on the Irish question during the 1850 s and 1860 s; his major contribution, contained in the first volume of Capital, based its accounts of agricultural change primarily upon the years 1860-1865.20 After 1867, he did not resume his studies of Ireland, and ventured comments in correspondence only on political matters; references to the land acts would fall under this heading. Although having a considerable interest in Irish events, most particularly in the Fenians, available evidence would suggest that this interest and knowledge was purely tangential. As indicated by the inclusion of the discussion on post-famine agriculture in Capital, Marx's primary concern was with the development of the capitalist mode of production. Therein, he had endeavoured to elaborate more fully on how the law of capitalist accumulation effectively incorporated Irish agriculture into the development of capitalism in England. 21 Insofar as this explanation coincided with the rising level of political activity in Ireland, he devoted considerable attention to those events, most particularly in their effect upon the English social formation. 22 In slight contrast,

20. Despite the numerous articles, Marx's major contribution was only in 1867 and concerned the research he had conducted for Capital. See Ellen Hazelkorn, "Karl Marx and Frederick Engels on Ireland: An Annotated Checklist, "forthcoming AIMS Bibliographical Series, no. 15, and "Capital," pp. 331-
338 .

21. See also Paul Bew, "The problem of Irish Unionism," Economy and Society, vol. 6, no. 1 (February 1977) p. 90.

22. Reference here is to Marx's involvement with the Fenians, a populist, nationalist secret society, formed in 1858. Primarily through a campaign initiated on behalf of imprisoned Fenians in English prisons by the International and the Reform League, Marx and Engels came to focus attention on the Irish national question. See Documents of the First International Minutes of the General Council (Moscow, n.d.) 3:171-174; 
Engels did begin full-scale research into Irish history, although never proceded past the first two chapters of the proposed History of Ireland. 23 By 1873, when the remnants of the International had

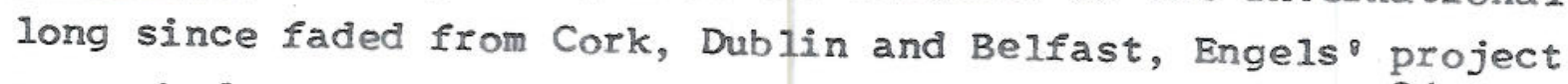
succumbed to more pressing political demands and issues. 24 Hence, a clear demarcation must be drawn across their writings, specifically the more important economic analysis of Marx, on the basis of their own terms of reference. These reservations should not, however, mitigate against a comparison between their writings, and events or developments in Ireland nor excuse their faults: it merely serves to place the writings into a more general context and to suggest that aside from Engels" unfortunately meager contribution, Marx did not seek to examine the Irish social formation.

How much should they have been aware of? Anyone reasonably familiar with events in nineteenth century Ireland will find obvious and inexplicable omissions in Marx and Engels' writings. Strangely, both men were silent about the level of industrialisation in Belfast, which in contrast to the steady decay and decline in craft and smallscale manufacturing in Dublin, remained a significant British centre for ship-building, engineering and textiles. 25 This deletion is particularly odd in light of Engels joint ownership of the Manchester cotton-thread firm of Ermen and Engels; Belfast enjoyed a sizeable trade in linen-thread with northern England. In addition, Marx and Engels ignored the increasing commercialisation of the south resulting from rising living standards following the

3:177-196; Kar1 Marx, "Memorial of the General Council of the International Working Mens Association to the Right Honourable Gathorne-Hardy, Secretary of State/The Fenian Prisoners at Manchester and the IWMA," Documents, 2:312-313; Kar I Marx, "Confidential Communication," Documents, 3:354-363; see further Marx's correspondence with Engels between 1867 and 1869.

23. For completed chapters, see MEI:210-269. A complete list of Engels" manuscript material and bibliography is given in Hazelkorn, "Checklist."

24. Engels to Sigismund Borkheim, beginning of March, 1872. An account of the International's incursion into Ireland can be found in John $W$. Boyle, "Ireland and the First International,"

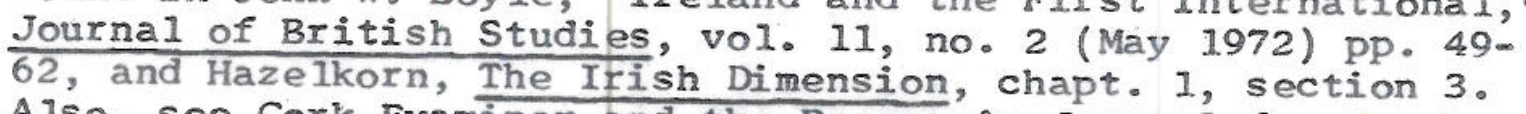
Also, see Cork Examiner and the Freeman's Journal for March 25 th and 26 th, 1872; J. P. McDonnell papers, State Historical Society of Wisconsin, Madison; Correspondence of \$. P. MCDonnell with Karl Marx, International Institute of Social History, Amsterdam, Ms。D3246-3248. 
famine, as well as the introduction of the railraod. 26

of coal and iron precluded imitation of the English pattern of industrialisation, but not industrialisation itself."27

Marx's figures for the decline experienced in textiles in the forty years after the Act of Union illustrates the emphasis he placed upon free-trade. While his figures reflect the trend substantiated by Engels" observations of 1856 which described "a total absence of any industry at all" in the south, there was no attempt to offer an explanation for this phenomenon beyond reliance upon the Union. 28 Indeed, except for a marked decline in textiles,

25. See Patrick Lynch and John Vaizey, Guinness's Brewery in the Irish Economy, 1759-1876 (Cambridge, 1960) P. 165; W. E. Coe, The Engineering Industry of the North of Ireland (Newton Abbot, 1969); Frank Geary, "The Rise and Fall of the Belfast Cotton Industry: Some Problems, "Paper delivered to the Irish Economic and Social History Society, 1977.

26. See Joseph Lee, "The construction costs of Irish railways, 1830-1853," Business History, vol. 9, no. 2 (July 1967) pp. 95-109, and "The provision of capital for early Irish railways, 1830-1853," Irish Historical Studies, vol. 16, no. 27. Lee, Modernisation, pp. 12-13; cf. James Connolly, Labour in
Irish History (Dublin: New Books, 1971) pp. 26-28.

28. Marx and Engels' position on the effect that the Act of Union had on Irish industry is somewhat ambiguous, although they did not appear to fall too deeply into the well-worn track of blaming the Union for all Ireland's ills. In Marx's Report on the Irish question to German workers in
1867 (MEI:131) he concluded that the introduction of Iree trade would naturally result in the weakening and disappearance of certain Irish manufactures. For a fuller discussion of Marx's position on this question, see Hazelkorn, "Capital." On the question of the impact of the Union upon Irish manufacturing, see R. D. C. Black, "Theory and Policy in AngloIrish Trade Relations, 1775-1800," Journal of the Statistical and Social Inquiry Society of Ireland (henceforth JSSISI), History of Ireland Since 1660, Studies in Economic and Social History (London, 1972) PP. 98-99; Conrad Gill, The Rise of the Irish Linen Industry (Oxford, 1925) p. 281 ; George the Famine (Clifton, New Jersey, reprint 1972) pp. 299-303. For a similar discussion on the effect of British legislation in the 17th century, see H. F. Kearney, "Mercantilism and Ireland, 1620-1641," in D. Williams, ed., Historical Studies, vol. I (London, 1958 ) pp. 59-68, and "Political Bakkground to English Mercantilism, 1695-1700," Economic History Review, vol. 11 (April 1959) pp. 484-496. For discussion of the guidelines of the revisionist school of Irish economic history, 
tamning and distilling by the mid-nineteenth century, ${ }^{29}$ Louis $M$. Cullen argues that industry on the whole remained prosperous into the 1850 s and 1860s. 30 An industrial crisis in the 1870 s spurned by British manufacturing goods flooding the Irish market acclerated the uncompetitiveness of traditional small-scale manufactures when compared with industrially produced goods. 31 This information would therefore clash with Marx's declaration in Capital that market towns and the petit-bourgeoisie were on the retreat as a result of emigration. 32 .

29. J. F. Burke in Outlines of the Industrial History of Ireland

see L. M. Cullen, "Problems iri the Interpretation and Revision of 18th Century Economic History," Iransactions of the

Royal Historical Society, 5th series, vol. 17 (1967) pp. 1-22;

"The Re-interpretation of Irish Economic Illstory," Topic, no. 13 (Spring 1967) pp. 68-77; and "The Value of Contemporary Printed Sources for Irish Economic History in the 18th Century," Irish Historical Studies, vol. 14, no. 54 (September 1964) pp. 142-155. ([Dublin], [1920]) suggests that the large export of cattle to England had serious repercussions for the leather industry, and the manufacture of glue and combs. English manufactures were provided with the raw materials which "could easily have been worked up at home." p. 211.

30. See also A. C. Davies, "The First Irish Industrial Exhibition: Cork, 1852," Ixish Economic and Social History, vol. 2 (1975) pp. 46-59.

31. For reaction by business see L. M. Cullen, Economic History; for reaction by trade unions to increasing competitiveness of the English-made goods, see the recording of meetings of the United Trades Association, 1860s, in the Freeman's Journal, and John W. Boyle, unpublished ms. on the United Trades Association. See further, D. L. Armstrong, "Social and Economic Conditions in the Belfast Linen Industry, 1850-1900," Irish Historical Studies, vol. 7, no. 28 (195051) P. 239; J.F. Burke, Outlines, pp. 198-199. Uncompetitiveness was not restricted to manufacturing but hit the provisions trade as well. J. Donnelly in The Land and People of Nineteenth Century Cork, Studies in Irish History series, 2nd series, T.W. Moody et al, eds. (London, 1975) discusses the situation with reference to Irish butter which found it increasingly difficult to compete with European butter because of its low standard. Also Cormac O Gráda, "The Beginnings of the Irish Creamery System, 1880-1914," Economic History Review, 2nd series, vol. 20, no. 2 (May 1977) pp. 285-290.

For discussion of the role of the Irish "Gombeenman," see Peter Gibbon and M. D. Higgins, "Patronage, Tradition and Modernisation: The case of the Irish "Gombeenman, "Economic and Social Review, vol. $6(1974-5)$ pp. 27-44; Peter Gibbon, 
Further, Marx's pronouncements about the prospects for an end to the religious divide in the community suggests a general ignorance of the situation. In proposing that Gladstone's Disestablishment Bill of 1867 would remove the "religious bulwark of English landlordism in Ireland" and result in the unity of Protestant and Catholic tenants against landlordism, Marx was merely repeating traditional and nationalist opinion that Protestant secret societies were artifically manipulated by England. This was also a view conveyed by Marx's daughter Jenny to Ludwig Kugelmann in 1869. 33 In general, both Marx and Engels displayed a remarkably simplistic notion of discord in Ireland, preferring a religious interpretation to a materialist analysis. Not until some rather cryptic remarks by Engels, in a letter to wilhelm Liebknecht on February 29, 1888, was there any indication that unity amongst the varying communities was more difficult than "false consciousness" would suggest.

At another level, Marx's deductions about post-famine Ireland present a gloomy pciture. In contrast to many of his contemporaries who were anxious to point out the benefits of the new English policy, Marx assessed the changes dialectically, careful to note the progressive developments, such as the concentration of "pigmy properties," as well as the distubance these changes had

"Arensberg and Kimball Revisited," Economy and Society, vol. 2 (1973) pp. 479-498. Perhaps after comparing the level of industry in Ireland with that of England, Marx and Engels chose to overlook it; but while Dublin and southern Ireland were no doubt comparatively weaker, it is surprising that Belfastwas completely ignored. Indeed, there is no indication that Engels considered travelling northwards during his three trips to Ireland in 1856, 1869, and 1891. Instead, his journies took him to the traditionally board. For a discussion of industrial development in Irelad, see Cullen, Economic History; L. M. Cullen, ed., The Formation of the Irish Economy, Thomas Davis Lectures (Cork, 1968); Lee, Modernisation. Cf. Engels to Marx, May 23, 1856; Marx,
"Outline Report," MEI:131-132; Capital 1:705. Marx was correct in his view insofar as those industries which depended exclusively on the home-market contracted; expanding firms were "as a rule export-oriented." Cullen, Economic History,
p. 157 .

33. Marx to Ludwig Kugelmann, April 6, 1868; Marx, "The Excitement in Ireland," NYDT, January 11, 1859; Jenny Marx to Ludwig Kugelmann, December 27, 1869. Cf. Peter Gibbon, The Origins of Ulster Unionism (Manchester, 1975); E. Rumpf and A. C. Hepburn, Nationalism and Socialism in Twentieth Century Ireland (Liverpoo1, 1978); Belinda Probert, Beyond 
brought to human life. ${ }^{34}$ It is, however, unfortunate that Marx based most of his judgements upón figures for 1860-1865, a period now understood to have been one of severe agrarian crisis - perhaps greater in intensity than that of 1879 which led to the formation of the Land League. ${ }^{35}$ For the most part, the years following the famine were prosperous; while subsistence farming was largely destroyed, commercial farming responded favourably to changed market conditions. 36 This took the form of expanded cattle and sheep herds in preference to tillage crops. 37 As increased incomes were

Orange and Green (Dublin, 1978): Paul Bew, Peter Gibbon and Henry Patterson, The State in Northern Ireland, 1921-72 (Manchester, 1979) pp. 2-3. For a discussion of the implications of Marx and Engels ${ }^{\circ}$ misunderstanding of unionism for them and their followers, see E. Hazelkorn, "Labour and Nationalism: Marx, Connolly, and the crisis of the Irish Labour Party," unpublished, 1980.

34. Hazelkorn, "Capita1," pp. 341;353; Cormac ó Gráda, "Kar I Marx and Post-Famine Ireland," Unpublished, n.d., p. 3.

35. See James S. Donnelly, "The Agricultural Depression of 185964," Irish Economic and Social History, vol. 3 (1976) pp. 3354: Joseph Lee, "Irish Agriculture: Review Article of $R$. D. Crotty, Irish Agricultural Production. Its Volume and Structure," Agricultural History Review, vol. 17 (1969) pp. 70-71. On the Land League, see Paul Bew, Land and the National Question in Ireland, 1858-82 (Dublin, 1978), and Samuel Clark, Social Origins of the Irish Land War (Princeton, 1979).

36. Cullen, Economic History, chapter 6; Bew, Land and the National Question, pp. 25-33; Donnelly, Land and People, pp. 130131; Lee, "Irish Agriculture," p. 65; Raymond D. Crotty, Irish Agricultural Production (Cork, 1966) pp.67-68; J. D. Chambers and G. E. Mingay, The Agricultural Revolution, 1750 1880 (London, 1965) p. 110. Cf. T. W. Grimshaw, "A Statistical Survey of Ireland from 1840-1888," JSSISI pt. 2 (December 1889) pp. 321-361.

37. Barbara Solow argues in The Land Question and the Irish Economy, 1870-1903, Harvard Economic Studies, vo1. 139 (Cambridge, Mass., 1971) p. 109, that land consolidation, which came about 1851, must be considered separately from the shift to pasture. That shift occurred because of price and labour shortages. I. M. Cullen presents similar evidence for shifts from tillage in the 18th century in Anglo-Irish Irade, P. 6. See further, R. D. C. Black, Economic Thought and the Irish Question, 1817-1870 (Cambridge, 1960) p. 240. Also see Hans Staehle, "Statistical Notes on the Economic History of Irish Agriculture, 1847-1913," JSSISI (1950-5I) p. 457; T. W. Freeman, Pre-Famine Ireland: A Study in HistoriCal Geography (Manchester, 1957) p. 71. 
associated more with this shift to livestock, it can be questioned whether the period Marx surveyed represented a true agrarian revolution. Despite brief remarks pointing to the increase in machinery and the "most rigorous economy of labour," that is an alteration in the organic composition of capital coincident with capitalist investment, he presented no evidence to support this contention. 38 In addition, there is no indication that agricultural output increased albeit prices and profits did. 39 Indeed, Marx's own evidence is unable to sustain this argument as he concentrated solely upon the shift in production.

There is no doubt, however, that both Marx and Engels quickly drew the significant conclusions about the famine, most notably its position as a crucial watershed in the Irish social formation. 40 Their optimism for the new landowners was shared by many of their contemporaries including the government. 41 The Encumbered Estates

38. Marx, Capita1, 1:708.

39. Ibid., 1:703. Cormac ó Gráda, "On Some Aspects of Productivity Change in Irish Agriculture, 1845-1926," paper prepared for the Agricultural History Session, Section C, 7 th International Economic History Conference, 1978, p. 13, and "Investment Behavior of Irish Landlords, 1850-1875; Some Preliminary Findings," Agricultural History Review, part II, vol. 23 (1975) pp. 139-155. See also Utsa Patnaik, "Capitalist Development in Agriculture: A Note," Economic and Political Weekly (Bombay), vol.6, pt. 39 (1971) pp. 123-130.

40. Lee, Modernisation, pp. 36-39; Cullen, Economic History, argues that while there is no doubt of its importance for Irish economic development, a "rise in emigration and a falling population would have been inevitable even if the Great Famine had not occurred," given the extensive sub-division of the land and the lack of industrial outlets. See also Crotty, Irish Agriculture (pp. 38-39). On p. 46, Crotty argues in contrast to Lee and Cullen that the famine did not mark a watershed in agricultural development.

41. P. G. Lane in "Management of Estates by Financial Corporations in Ireland after the Famine," Studia Hibernia, vol. 14, p. 87, states: "The Encumbered Estates Court, as it existed from 1849-1858, was a bid by England to settle the Irish Land Question within the framework of landlordism by the introduction of commercial principles into estates management. As such a measure it preceded Gladstone's efforts at Settlement through dual ownership and preceded the establishment of a tenant proprietary." For a discussion on the introduction of free trade as a means to solve the land question, see H. J. Perkin, "Land Reform and Class Conflict in Victorian Britain," in J. Butt and I. F. Clarke, eds., The Victorians and Social Protest (Newton Abbot, 1973) pp. 177-217. 
Acts, introduced by Lord John Russe11's Whig government in 1849, was viewed as a progressive vehicle leading to the expulsion of indebted landlords and the entry of enterprising capitalists. Yet, the expected rush from England did not occur; while some of the new owners did represent a new breed, only a proportion of land actually changed hands. 42 For the most part, these new owners - members of the existing Irish bourgeoisie who desired to own land as a symbol of status rather than as a source of capitalist investment - were content to copy their predecessors and live elsewhere. ${ }^{43}$ Those

42. Of the new owners on the Donegall estates, W. A. Maguire remarks: ". . . It had been hoped when the 1849 Act was passed that the establishment of free trade in land would attract British capital and British landlords to Ireland. This hope was almost completely disappointed. As Prafessor Becketter succinctly puts it: 'Between 1849 and 1857 over 3,000 estates were sold under the terms of the Act. But there was no influx either of landlords or of capital: of some 7,200 purchasers only about 300 came from England or Scotland, and they contributed less than $£ 3,000,000$ out of the $\$ 20,000,000$ paid in purchase money." Excerpt from "Lord Donegall and the Sale of Belfast: A Case History from the Encumbered Estates Court," Economic History Review, 2nd series, vol. 29, no. 4 (Kovember 1976) p. 584. Marx stated that $1 / 6$ th of the land changed hands (Marx to Engels, April 14, 1870); Engels stated I/5th (Engels to Marx, April. 15, 1870): cf. Lee, Modernisation, who presents a figure of $1 / 7$ th (p. 38), while Cullen offer's the larger figure of $1 / 4$ (Economic History, P. 138). See also Donnelly, Land and People, p. 130; Lee, "Irish Agriculture," and Moritz Bonn, Modern Ireland and Her Agrarian Problem, trans. from the German by T.W. Rollecton (Dublin, 1906) P. 60.

43. Elizabeth Hooker, Readjustments of Agricultural Tenure in Ireland (Chapel Hill, 1938) after surveying residences of owners of Irish landed estates over 100 acres in 1870 showed that over half of the owners were to some degree absentee. (p. 24) See the following data:

$\frac{\text { Residence of Owners of Irish Landed Estates (over } 100 \text { acres) }}{1870}$

1. Resident on or near property

2. Resident usually in Ireland, occassionally on property

3. Resident elsewhere in Ireland

4. Resident usually out of Ireland, but occassionally on property

$41.2 \%$

$2.8 \%$

$32.9 \%$

5. Resident rarely or never in Ireland

6. Public or charitable institution, or public company

7. Not ascertained

Absentee in the generally known sense, that is out of the country, is shown to be not as great as generally assumed, only 10.6\%. See also E. D. Steele, "Tenant-right and Nationality in 19th Century Ireland," Proceedings of Leeds PhiloSophical and Literary Society, vol. 15, pt. 4 (December 1973) 
landlords, such as Allan Pollack, and the London financial and insurance companies, who attempted to apply progressive and modern techniques to farming found their efforts stymied by a traditional and recalcitrant tenantry. 44 Recognition of tenant-right proved insufficient to give adequate security to small tenures on short leases. On the other hand, landlords were hesitant to grant longer leases or to attempt meaningful improvement for holdings under 15 acres. In summary, the perpetuance of small, sub-divided holdings farmed at subsistence level by a tenantry standing outside the market economy remained a serious stumbling block for capitalist growth a point both Marx and Engels had recognised quite early on. 45

The Great Famine, changes in market conditions (rollowing the repeal of the Corn Laws and increased demands for meat ${ }^{46}$ ), the introduction of free-trade principles, and the virtual decimation of the agricultural proletariat helped effect the transition towards pasture agriculture, and the growing capitalisation of the agrarian sector. While changes in landownership were not earth-shattering Marx had felt the number of owners remained at $8,000-9,000$ - the real change in class structure came among the class of tenant-farmers. 47 As a result of the 1840 s, medium to large commercial farmers - those who rented upwards of 15 acres - were scarcely affected by the: famine; indeed, it was these farmers who in the 1870 s formed the backbone of the Land League (as they had done of the Tenant League in the 1850s) and emerged at the end of the century as the independent rural bourgeoisie, having effected the most dramatic revolution in landownership. In the period immediately subsequent to the

44. Iane, "Management," pp. 67-89; 0. Robinson, "Iondon Companie as Progressive Landlords in 19th Century Ireland," Economic History Review, 2nd series, vol. 15 (August 1962) pp.103118; Solow, Land "Question; W. A. Maguire, The Downshire Estates in Ireland (Oxford, 1972); P. G. Lane, "An Attempt at Commercial Farming in Ireland after the Famine, "Studies, vol. 61 (Spring 1972) pp. 54-66; Cullen, Economic History, pp. 139-140.

45. For example, see Frederick Engels, The Condition of the Workclass in. England, quoted in MEI:40-41.

46. Moritz J. Bonn, Modern Ireland (p. 37) suggests that the repeal of the Corn Laws cannot be held responsible for the fall in the price of corn into the 1880s."... It can be said with tolerable precision that no corn duties of fairly bearable dimensions would have been able to stay the great fall in the price of corn during the eighties. Up to that time it was not so much the fall in corn prices as the rise in meat prices which had caused the prevelence of cattlebreeding in Ireland." See also G。 Kitson Clark, "The Repeal 
famine, the larger farmers benefited at the expense of the small farmers whose holdings had been centralised. As Joseph Lee said, "the majority of the rural bourgeoisie had always been bourgeoisie who now flourished on the graves of the proletariat." 48

Whereas prior to the famine, labourers, the true agrarian proletariat, had numbered almost one-and-a-half milion, by 1881 their numbers had declined by half to just over 800,000 . The significance of this reduction is noted in the increase in wages, the fall in tillage in the early 1870s, the substitution of the scythe for the sickle, and the introduction of other farm machinery in the last quarter of the century. 49 David Fitzpatrick records Lord John Browne noting that he was unable to provide information about "agricultural labourers in Mayo, because they do not exist as a class in this country. Their place is taken, with great advantage to themselves, and everybody, by the sons of tenant farmers." Fitzpatrick argues that as the force of "farm workers shrank, it became not only increasingly dominated by farmers assisting relatives - often doubling up as occasional wage earners - but also by labourer occupiers. Indeed, it seems plausible to suggest that Irish labourers as a class became less rather than more distinct from Irish farmers in the aftermath of the Famine. "50

\footnotetext{
of the Corn Laws and the Politics of the Forties," Economic History Review, 2nd series, vol. 4, no. 1 (1951) pp. 1-13. 47. Marx to Engels, April 15, 1870.

48. Lee, "Irish Agriculture," p. 65. On the structural alteration in agricultural class formation, see Clark, Social Origins, P. 114, who shows that labourers decreased from $56 \%$ to $38 \%$ (from 1841 to 1881), while farmers, in the same period, increased from $42 \%$ to $60 \%$ of the adult male agricultural labour force. In particular, farmers holding 20 acres or less increased from $15 \%$ to $17 \%$, and those with between 21 and 50 acres increased from $9 \%$ to $14 \%$. 49. Cullen, Economic History, pp. 135-137. See David Fitzpatrick,
"The Disappearance of the Irish Agricultural Labourer, 1841-
1912," Irish Economic and Social 1912," Irish Economic and Social History, vol. 7 (1980)

50. Fitzpatrick, "Disappearance," pp. 69, 77.
} 
The impact of this remarkable phenomenon was, however, unfortunately lost on Marx, whose brief account in Capital seemed to assume the continued proletarianisation of the small farmer, adding to the existing reserve army of labour. Likening the classic transformation of England to post-famine Ireland, Marx noted that "sine the catastrophe of 1846 .. [ [the small farmer has] begun to form a fraction of the class of purely wage-labourers, a special class connected with its wage-masters only by monetary relations." 51 While eviction and emigration certainly had its toll among the small holders immediately after the famine, evidence suggests that eviction ceased to play a dominant role after the early 1850s.52 A study by cormac ó Grada also argues that small holders were able to withstand the transformation into full-fledged agricultural proletarians by supplementing their subsistence holdings with seasonal wage-labour - in effect, as Kautsky would argue in his major work The Agrarian Question, seasonal migration was a means of "consolidating peasant property."53 Migration from the poorer west to the large capitalist farms of the east, or from one part of the county to another, enabled this class to hide its otherwise precarious position; when the National Land League emerged in 1879, spurned as a large farmers ${ }^{\circ}$ reaction to rent increases and advocating direct ownership, small holders translated the demands of peasant proprietorship into a messianic key to their own economic solvency. 54

While Engels by 1888 recognised that the tenantry desired only to own land, he had joined with Marx in assuming that its demise, under the impact of mortgage repayments, would swiftly follow. Unaware of the real kernal of the proprietary movement,

51. Marx, Capita1, 1:706-707.

52. Solow, Land Question, pp. 53-57; Bonn, Modern Ireland, p. 67.

53. ó Gráda, "Demographic Adjustment and Sgasonal Migration;" Banaji, "Kautsky," p. 38; Bonn, Modern Ireland, pp. 53-54.

54. The use of the term "peasant" proprietorship is actually misleading as it suggests we are discussing a movement advocating ownership by subsistence, non-commercial holders. While there is no doubt that the Land League began in county Mayo by Michael Davitt among small holders, the real backbone and victors were the large capitalist farmers who desired ownership rather than rental. It is this movement which effectively signals the rise of an independent rural bourgeoisie. See Bew, Land and the National Question, p. 87, and clant, Social origins. 
he had also implied a much quicker move towards the proletarianisation of small farmers, and hence social revolution, than actually occurred. Despite this discrepancy, there is no doubt that the pattern of capitalist growth first noted by Marx and Engels has now emerged in the long run. Afterall, the proportion of agricultural land held by small tenures has continued to diminish, revealing a classic pattern of capitalist centralisation of land and consolidation of ownership into larger units and a small number of hands: whereas farms of $1-30$ acres were $65 \%$ of total holdings in 1917 and held 24\% of agricultural land, by 1931 they were $57.9 \%$ and held only $22.5 \%$ of land. In 1960 , the respective figures were $49.6 \%$ and $17.4 \% .55$ As a final point, it is extremely unlikely that mortgages, as Engels suggested, rather than competition (viability of farm units has increased from 15 acres in 1900, to 40 acres in 1960, to 80 acres in 1976) and the state (particularly marked since entry in 1973 into the EEC through the impact of the Farm Modernisation Scheme) were responsible for the demise. 56 Marx had used figures for 1851 and 1861 to substantiate his claim that centralisation of holdings, allowing primitive accumulation, was occurring. Given the experience of the agricultural revolution in England, and the continuing rise in profits despite falling productivity and population, Marx had argued that an additional 921, 174 people were destined to emigrate. Depopulation would bring about the centralisation of holdings under 100 acres. 57 Marx based this analysis upon the 1861 census returns. 58

55. F. S. L. Lyons, Ireland Since the Famine (London, 1973)

56. Figures from An Foras Taluntais, quoted in Sinn Fein the Workers" Party, The Irish Indstrial Revolution (Dublin, revised ed., 1978) P. 28; see also figures on agricultural holdings, Statistical Abstract (Dublin, 1976). Cf. Engels" optimism regarding the demise of the small-holder through mortgage debt with the view expressed by Marx in both Class Struggles in France, 1848-1850 (New York, 1964) pp. 117-120, and The 18th Brumaire of Louis Bonaparte (New York, 1963)

57. Marx, Capita1, 1:711; see further Marx, "Outline Report," MEI : 126-139, and "Notes," MEI:120-125. O- Gráda, "Investment Behavior," argues on page 144 that in 1870, landownership in Ireland was more concentrated than in neighbouring England. Similarly, M. Bonn, Modern Ireland ( $p .60)$, states that by 1876 , about $50 \%$ of the country was held by 700 persons.

58. Evidence of this can be found in Marx's manuscript notes held in the International Institute of Social. History, Amsterdam, Ms B/91A. Cf. with Barbara Solow's computations for 1861 in 
He computed the following figures for land-holding in Ireland in 1864 :

Percentage of Farm Holdings by Acre for 1864

$\begin{array}{cccc}1-5 \text { acres } & 5-15 \text { acres } & 15-30 \text { acres } & 30 \text { pius acres } \\ 15 \% & 32 \% & 25 \% & 28 \% \\ (82,037) & (176,368) & (136,578) & (158,135)\end{array}$

(Note: the total number of units is indicated in parenthesis.)

Questions arise, however, over Marx's projections for continued centralisation of holdings. Contrary to his view, history has shown that centralisation did not proceed as thoroughly as he had envisaged, and that Ireland has maintained a significantly large numer of small holders on the land. Barbara Solow argues that "the great change in the number of holdings was virtually completed - [between 1845 and 1851]. Between 1851 and 1861 [the period Marx declared as destroying 'principally' all farms under 15 acres] the decrease was negligible; between 1861 and 1871 only about -4 percent; between 1871 and 1881 about -3 percent." Furthermore, Solow points out that while the actual number of holdings fell sharply between 1845 and 1853, from 1853 to 1861 , they rose, and only after 1866 did they again begin to decline and then gradually. 59

The significance of these figures and their correspondence to the level of centralisation suggest a discrepancy between Marx ${ }^{8}$ calculations on capitalist growth and Irish reality. Instead of centralisation proceeding at a similar pace throughout the remainder of the century, evidence points to a significant reduction in that speed. Certainly it is difficult to fault Marx entirely for being unaware of this change after 1851, as it seems likely that he based his deductions on a general comparison of agricultural statistics for the entire period rather than on a meticulous accounting of years within that period. Yet, while he calculated total farm holdings to be 601,771 in 1864, a figure comparable with Solows's comments, the fact that he did not observe any fluctuation in the total number of holdings after 1853 casts dispersions over his familiarity with

Land Question, p. 93.

59. Solow, Land Question, pp. 92-94. 
the situation. Insofar as this generality ignores an actual increase in the total holdings, and hence the staying-power of the small-holder - Marx's analysis would assume only centralisation his assumptions of capitalist penetration into agriculture deserve more serious attention. That is to say, while many small holdings were welded into larger one, they account for almost half of all landholdings we 11 into the 1890 s. 60

These remarks should be borne in mind while examining the effect of the land agitation of the 1850 s and after, to which Marx addressed himself in numerous articles. 61 Whilst supporting these agitations, he and Engels seemed surpri singly unable to relate the effect of these demands to their general over-view of Irish economic growth, and hence the emergence and extension of capitalist relations of production. Why this contradiction? Despite giving varied attention to the land question in many of their writings, no clear definition of a peasant is offered; instead, it appears that the term was used generically to refer to all agriculturalists, except landowners. and Germany, published in 1894, Engels drew attention to the small peasant, whom he described as "the owner or tenant - particularly the former - of a patch of land no bigger, as a rule, than he and his family can till and no smaller than can sustain his family."62 The key elements here are the size of the holding and the subsistence level of existence. At various times in other writings, other sub-groups were noted, most especially the medium and large peasant, both of whom employed wage-labour, although the latter most frequently. As Mayer has pointed out, this sub-classification can be misleading as it is based only upon Engels" works; "Marx did not stress the

60. Bonn, Modern Ireland, pp. 47-49.

61. For example, Marx, "Parliamentary Debates/The Clergy and the Struggle for the Ten Hour Day," NYDT, March 15, 1853; "War Question/British Population and Trade Returns/Doings of Par-
liament," NYDT, August 24, 1853, MEI:67-69.

62. Contained in Marx and Engels Selected Works (London, 1970)
vol. 3, p. 459 . 
sub-classification so much" relying at times only on a small/large dichotomy. 63

The difficulty with the vagueness of the term peasant is, however, not with its varied usages by Marx or Engels, but rather that it tends to confuse modes of production, precisely that of feudalism and capitalism. In other words, the term farmer, whether the owner or renter of the land, should be used to describe the "peasant" engaged in capitalist agriculture, that is producing surplus-value from wage-labour, and peasant to refer to the small holder locked in a subsistence level, pre-capitalist economy. Without such a clear demarcation, confusion sets in. It becomes unclear whether the large peasant is part of a feudalistic class or should be classed as the rural bourgeoisie. Despite Engels'efforts to attempt a more precise analysis of agrarian class structure, such terms and insight were generally ignored when addressing the Irish situation.

In this case, the tenantry, which was at times termed the peasantry, thereby adding to the confusion, was treated en bloc. 64 Whilst treatment of land centralisation and eviction implies a distinction between large and small tenant-farmers, Marx's concern with the general "laws of motion" of capitalism precluded a deeper analysis of land structure, the forces responsible for the postfamine re-adjustment, and other such factors. Although cognisant of the tenant movement, he tended to assume the laws of capitalism would swiftly engulf and hence proletarianise the smaller tenants. As Mayer notes in his study, Marx treats the small holder as a "doomed class." Unlike his analysis of the concentration and centralisation of industrial capital wherein he accounted for counteracting tendencies, his rather sketchy attention to agriculture, and agrarian class structure, did not see its path of development being possibly retarded by specifically agrarian tendencies, such as the resistance to proletarianisation by the small tenantry. It can, therefore, be argued that while Marx noted, as in the case of France, how peasants clung to subsistence plots which gave them only the "pretense of being a private proprietor," he never seriously doubted that the small peasantry would either be enlightened and turn to land

63. Mayer, "Politics of the Peasantry," p. 102. Cr. Lenin, The Development of Capitalism in Russia, Collected Works, vol. 3 (Moscow, 1964), and "The Agrarian Question and the 'Critics of Marx", vol.5, pp. 218-219 especially.

64. The effect of this misuage of the term peasant is to confuse the pre-famine landlord-tenant relationship with the post-
famine period. 
nationalisation as the only rational alternative or suffer defeat. 65 In effect, what is strikingly absent from Marx"s work is "any serious analysis of the roots and contents of 'property fanaticism based on nominal property. "66 The idea of "nominal" of "phantom" ownership was ignored; in the Irish case it was precisely the strength of a historico-mythical sense of celtic ownership conveyed to small holders through nationalist interpretations of the 15 th and 16 th century land confiscations, which fueled the land agitations of the 1870 s and later. 67 Let's turn to look very briefly at what effect the tenants: movement had upon class structure.

The Tenant League of the 1850 s should more accurately be termed a farmers movement, thereby delineating between farmers who rented land and hired wage-labour to work it, and the peasants who held rack-rented leases in pre-famine days. Shrouded behind demands against the "injustices of the land system," it was comprised primarily of large eastern grain farmers whose opportune interest in questions of tenant-right coincided with the economic crisis of the 1850s. 68 The drive for peasant-proprietorship, seen

65. Marx, Class Struggles, p. 119; see further Karl Marx, "The Nationalisation of the Land," The Internathonal fierald; June 15 ; 1872 , and $E_{0} H$. Carr, "Marx, Engels and the Peasant," The Bolshevik Revolution, 1917-1923, vol. 2 (London, 1952) Note C, pp. 385-393. R. D. C. Black, Economic Thought (pp. 24$25,240-242)$ suggests that schemes for nationalisation as Marx and Engels proposed were completely alien to the Irish peasantry, who were generally imbued with the notion of dishonoured celtic landowners. There was, in fact, a general lack of interest "in any schemes of utopian radicalism." Economists in general, inclusive of Marx, tended to underestimate the peasants desire to hold onto land.

66. Mayer, "Politics of the Peasantry," p. 149; cf. Lenin, The Agrarian Programme of Social-Democracy in the First Russian Revolution, 1905-1907, CW:13, p. 290, where he remarked on the behavior of the small farmer to his land: "The small farmer, at all times and throughout the world, becomes so attached to his farm (if it really is his farm and not a piece of the landlord's estate let out in labour-service, as is frequently the case in Russia) that his "fanatical" defense of private ownership is inevitable at a certain historical period and for a certain space of time."

67. Lee, Modernisation, pp. 95-97; Bew, Land and the National Question, pp. 217-232; Fitzpatrick, "Disappearance," pp. 67importance that Marx felt the land question held for the Irish national question, and above-all the potential for social revolution in England.

68. Bew, Land and the National Question, pp. 34-38; Lee, Modernisation, pp. 39-41; Donnelly, Land and People; Clark, Social 
by nationalists as the Irish answer to English landlord-dominated agriculture, quickly superseded these demands for tenant-right by the 1870s. 69 The Land Acts, first introduced by Gladstone in 1870, were to go half-way towards meeting this aim. Whatever about the various schemes for easing sales of land through generous loans and grants, the number of those able to purchase holdings were small evidence of the need for recurrent pieces of legislation in this field (e.g. 1870, 1881, 1885, 1891, 1903).70 Nevertheless, the effect was electric, and regardless of ability, the general cry among tenants by the 1870 s was for proprietorship. The landhungry desires of the population emerged from the demands of land agitation and accompanying prosperity, a feature of the 1870 s and after, and not from disease and emigration of the 1840 s. 71

The Land League, emerging in 1879 as the political response to the agrarian crisis of that year, took the idea of peasant proprietorship further along the road than any previous movement. Enshrining the idea of ownership, it succeeded in drawing support from both small farmers who had only marginally shared in the prosperity of the post-famine years, and large farmers (upwards of 15 acres of good land) who joined in an attempt to preserve their gains.72 The

Origins, pp。211-214。

69. See E. R. R. Green, "Agriculture," in R. D. Edwards and I. D. Williams, eds., The Great Famine (New York, 1957) for an account of various schemes for solving the land question, as well as R. D. C. Black, Economic Thought, and W. L. Burns, "Free Trade in Land: An Aspect of the Irish Question," Iransactions of the Royal Historical Society, 4 th series, vol. 31 (1949) pp.61-74. Solow, Land Ruestion (pp. 129-130) makes the following comment on the peasant-proprietary movement, although her remarks on Davitt are rather unfair: "The proposition that the land of Ireland belongs to the people of Ireland? is a sentiment to which we may all subscribe. It is a nationalist political slogan. It is an entirely different proposition from maintaining that every small tenant in County Mayo should be encouraged as a matter of economic policy to remain on his substandard holding. It was the genius of Fintan Lalor to see that the two could usefuliy be confused for revolutionary ends, and the greater genius of $D_{a}$ ivit not only to perceive but to implement the vision."

70. The increasing ease of purchase offered by the cummulative land acts illustrates that despite theix desires for ownership, tenants were rational, economic beings. Hence, while he should have been glad to purchase land under the Ashbourne Act, it was not until the more providential. Wyndham Act of 1903 that the vast surge into ownership occurred. 71. See W.A. Dunning, "Irish Land Legislation Since 1845," Poli-
tical Science Quarterly, vol. 7 , no. 1-3 (1892) pp. $57-79$, 
economic implications of the strategy were, however, ominous from a long-term perspective of economic gain. Whilst instilling a sense of self-respect into a dejected and poverty-striken small tenantry, the issue of peasant proprietorship dangled before them the idea of economic prosperity. There was, however, no rational basis to substantiate the belief that ownership would convert inadequate holdings into thriving economic concerns. ${ }^{73}$ Yet, the politics of the land question had always revolved around the emotional issue of tenure - who controlled the land and how much rent was paid - a question that politically-speaking had a magnetic nationalist appea1.74 The substantive question, that of the size of the holdings, as Engels had been clearly cognisant of as early as 1844 , was tackled by only a few. 75 Michael Davitt, Fenian turned Land Leaguer, found his ideas on land nationalisation ignored, and Engels was forced to admit that he remained only a "symptom."76

In conclusion, the famine witnessed the beginning of a fundamental structural change in the economy. 77 The eastern half of the country experienced the most marked change with a decisive shift to livestock and capitalist farming; the more densely populated west, with small units and poorer soil, sought tofutilise its labour. most efficiently in tillage production on family-run and oriented

500-521; S. J. Lynch, "Land Purchase in Ireland," JSSISI, part xciii (1912) pp: 1-16; H. Sherman, "State-aided Land Purchase Under the Disestablishment Act of 1869," Irish Historical studies, vol. 4 (March 1944) pp. 58-80; E。 $\frac{\text { D. }}{\text { D }}$ Steele, Irish land and British Politics (Cambridge, 1974): for a critical interpretation of the land acts, see Solow, Land Question. Cf. Solow with O Grada, "Aspects of Productivity Change," PP. 12-13, and "Investment Behavior," pp. 139-

72. Bew, Land and the National Ruestion, pololf. Intervention by several dozen farmers ${ }^{\beta}$ clubs in the Land League ${ }^{\prime}$ s affairs dates from the League conference at the end of April 1880. Also see Clark, Social Origins, pp. 214-220.

73. Lee, Modernisation, pp. 99-105.

74. See Crotty, Irish Agriculture, pp. 62-63.

75. Even the question of rent was in itself somewhat spurious, in that no matter whether it was lowered or even abolished, small holders would have been unable to survive. See Donnelly, Land and People, p. 199:

76. Engels to Edward Bernstein, August 9, 1882. Traditional accounts of the Irish land question have pointed to landlordism as the source of the problem. For a clear refutation of that approach, and support for Engels" call to examine the size of the holdings, see Robinson, "London Companies, "p. 103. 
units. Population pressure was an important variable in whether farms could take advantage of the changed market conditions. 78 The combination of dense population, small farms, and no possibility of a profitable tillage crop proved fatal. The west remained locked in a precapitalist world while the east partook of the opporunities that the famine had opened up.

\section{iii}

From the above discursive review of post-famine agricultural adjustment, it is apparent that Marx's assumptions of capitalist development in agriculture did not progress in Ireland as neatly as he described in Capital. While land holdings underwent considerable centralisation, it neither occurred with the swiftness nor evenness that he had expected. Obviously free trade did aidfentralisation, but in the final analysis the transference of land from small to large holdings were prompted by population density and market conditions, and did not cause a great upheaval in the actual number of holdings. The dramatic decimation of the agricultural proletariat, leading to severe labour shortages, remained a significant contributor to the preservation of the otherwise "doomed" smali tenant. And finally, the capitalist farmer was not very enterprising; his appearance after the famine was slow to mature, and when a rural bourgeoisie ultimately emerged at the end of the century, it did not prove to be as efficient nor keen an agriculturalist as its European counterpart.

In seeking to locate why Marx's prognosis for Irish agriculture veers from actual developments, it is necessary to examine more closely the metayage route he out lined in Capital. To facilitate that procedure, consideration of Lenin's study of the development of capitalism in Russia serves as a useful foil. Lenin's work is particularly apt because he sought to adopt Marx's analysis of the capitalist mode of production to the Russian experience; in so doing, he expanded upon what were only preliminary remarks on primitive accumulation, andhence, offered a much more extensive 
analysis of agrarian capitalism. Furthermore, Lenin, in contrast to Marx, produced evidence to suggest that several routes to the capitalist mode of production could (simultaneously) exist. It is on the basis of this conclusion, which was undeniably grounded in his political debate with Narodnik theories, 79 that comparison with Marx proves most stimulating. If Marx's assessment of capitalist penetration into agriculture proves lacking, can Lenin's more attentive analysis offer some key to our understanding of the fomer's omissions?

In The Agrarian Programe of Social Democracy in the First Russian Revolution, Lenin refered to two routes to capitalist production. His position argued that Russia in 1903/5tood at the crossroads of capitalist development; the choice of which path was to be taken towards that end-pointidepended upon a class analysis of the situation. The following excerpt outlining the two routes as he saw them deserves to be quoted in full. 80

But there may be two forms of that development. The survivals of serfdom may fall away either as a result of the abolition of the landlord latifundia, i.e. either by reform or by revolution. Bourgeois development may proceed by having big landlord economies at the head, which will gradually become more and more bourgeois and gradually substitute bourgeois feudal methods of exploitation. It may also proceed by having small peasant economies at the head, which in a revolutionary way, will remove the "excresence" of the feudal latifundia from the social organism and then freely develop without them along the path of capitalist economy.

Those two paths of objectively possible bourgeois development we would call the Prussian path and the American path, respectively. In the first case, feudal landlord economy slowly evolves into bourgeols, Junker landlord economy, which condemns the peasants to decades of most harrowing expropriation and bondage,

79. For instance, see Lenin, Agrarian Programme, CW:13. Kautsky's Agrarian Question was also written partially as a response to refornst critics of Marx who cited the increase in the number of small holders in Germany as a refutation of the general laws of capitalism. As an example of this argument, see D. Mitrany, "Marx Against the Peasantry: A Study in Social Dogmatism (London, 1951), and "Marx Versus the Peasant," in T. E. Gregory and H. Dalton, eds., London Essays in Economics: In Honour of Edwin Cannan (London, 1927) pp.319-376. For a refutation of that argument, see Lenin, "Capitalism in Agriculture," Zhizu, January-February 1900, CW 4:109-69, especia.1y pp. 131-132. 80. Lenin, Agrarian Programme, CW 13:239; "Preface to the Second
Edition," Development of Capitalism in Russia, CW $3: 32-34 ;$ 
while at the same time a minority of Grossbauern ("big peasants') arises. In the second case there is no landlord economy, or else it is broken by revolution, which confiscates and splits up the feudal estates. In this case the peasant predominates, becomes the sole agent of agriculture, and evolves into a capitalist farmer. In the first case the main content of the evolution is the transformation of feudal bondage into servitude and capitalist exploitation on the land of the feudal landlords - Junkers. In the second case the main background is transfor mation of the patriarchal peasant into a bourgeois farmer.

We can dismiss consideration of the Prussian path for it yields no useful comparison with Ireland. 81 by which independent peasant production becomes dominant, requires the destruction of feudal landed property and its replacement by bourgeois property ownership through, for example, the universalisation of free trade. This leads inevitably through increased levels of accumulation and competition to the emergence of the capitalist farmer who hires wage-labour. Russia had only one path before her, that of capitalism; what form that development took was, Lenin had argued, dependent upon class struggle. In the Russian example, the choice was between the landlords' programme for reform, and peasant agrarian revolution. The latter would lead to a rapid transformation of feudal social relations, while the former would necessitate a slower transition. If the latter was unsuccessful, then, Lenin argued, the first route would be pursued. "It is an incredibly slow and incredibly painful road for the broad masses of the peasantry and for the proletariat, but it is the only possible road for capitalist Russia if the peasant agrarian revolution is not victorious." 82

A look at Lenin's two-pronged analysis of transition suggests a re-examination of Marx's analysis of the "metayage" transition as illustrated by the English experience. Indeed, as Hindessiand Hirst

"Notebooks on the Agrarian Ruestion," CW 40. See also Barry Hindess, "Lenin and the Agrarian Question in the First Russian Revolution," Theoretica.1 Practice," no.6 (May 1972) pp. 3-19. For an interpretation of Lenin on the agrarian question, see George D. Jackson, Jr., Comintern and Peasant in East Europe,
$1919-1930$ (New York, 1966) pp. 29-40.

81. See Barry Hindess and Paul Hirst, Pre-Capitalist Modes of Production (London, 1975) p. 259. The Prussian path is illus trated by the transformation of the feudal Junker economy "into capitalist production by the landlord acting as the

capitalist, without the intermediary function of the tenant
farmer. Futhermore, the Junker landiord retains control 
suggest in their outline of the "variants" within the feudal mode of production, there may be three paths to agrarian capitalism, of which Marx"s"metayage"system is only one. 83 Lenin's Prussian and American routes offer two alternatives, שach depending upon prominent social relations - the form of rent, political/economic strength of the landlord class, the power of the state, and class relations. If we take Marx"s "metayage" route as an adequate description of transition fostered by the famine, free trade and changed maxket conditions, whereby the landlord acted as a progressive agent of the transition to the capitalist mode of production, Lenin's second route, that of peasant proprietorship, may be demonstrative of that emergent trend witnessed under the Land Acts, which saw the transformation of the tenantryinto independent proprietors. Once land became the means of production held in private ownership, the law of capitalist competition would come into full force. The ineficient and smaller farmers would be driven from the market as sellers of commodities of food stuff, and become sellers of the commodity labour-power. It seems likely that it was this picture which Engels envisaged in his 1888 interview.

Despite the antagonistic nature of these two routes - one demands the expropriation of the small tenantry, their reorientation as an agricultural proletariat, andthe imposition of the capitalist farmer, "while the other requires the removal of the landlord class and the emergence of an independent farming class, the rural bourgeoisie - these routes may co-exist within different regions of the same country at the same time. In this manner, "metayage" might accurately depict actions undertaken by the more progressive landlords immediately post-famine, while peasant proprietorship came to dominate by the latter part of the century. 85 In contrast to the over the labourers which are different from and additional
to those of wage-form (tied-housing, allotments, etc.)" This
path is different from the metayage route proposed by Marx, path is different from the metayage route proposed by Marx, as the latter sees the imposition of the capitalist farmer between the landlord and the labourer.

82. Lenin, Agrarian Programme, Cw 13:289.

83. Hindess and Hirst, Pre-Capitalist, pp. 255-259. Cr. Maurice Dobb, "Transition from feudalism to capitalism," Capitalism,
Development and Planning (New York, 1967) argues that Marx drew attention to "two roads" of transition. (pp. 12-14) Dobb's illustration, however, confuses industrial and agrarian capitalism. "According to the first... "the producer becomes a merchant and a capitalist... According to the

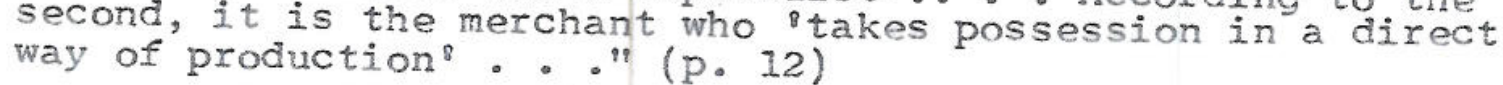


the Russian situation, as explained by Lenin, peasant proprietorship has been in Irelanda slower form of transition; the reluctance of the small holder to give up his land in the face of obvious inefficiency has provided proof of that. Hence, while large capitalist units now (1976) control upwards of three-quarters of agricultural land and agricultural produce, small holders have been amazingly
stead-fast.

If this two-pronged analysis of capitalist development can be applied to Irish agriculture, then we can possibly reveal the source of inadequacy and frustration with Marx's overly-optimistic version of transition. Certain factors aforementioned help account for his stance. The importance of timing deserves to be mentioned again; further, as Marx did not pretend to present an analysis of transition to capitalism but only of the capitalist mode of production, his own work was too superficial to provide the needed evidenos. His more obvious attempt to see development in Ireland as "mimicing" that of England would not have provided the required tools of analysis either. Although he did account for differences in demand for labour - agriculture sees an absolute fall in labour while industry only a relative decrease - he did not go far enough to suggest dissimilarities in the laws of development. He seemsinstead to have assumed an affinity in speed and efficiency between agrarian and industrial capitalism which has been largely unsubstantiated in reality. In other words, he was unfamilar with what Lenin and Kautsky later recognised were the specific laws of the penetration of capitalism into agriculture. Finally, as the Irish case illustrates, he did not adequately consider peasant proprietorship as an alternative route to capitalism. He failed to take significant account of the tenant movements, tending to view their aims of only peripheral importance to economic developments; in a sense, he viewed the demands as characteristic of a pre-famine peasantry rather than the birth-cries of a rural bourgeoisie.

Karl Kautsky in his pioneering work entitled The Agrarian Question (1899) greatly expanded upon the preliminary remarks made by Marx in Capital. 86 Tackling the question of the differences between agrarian and industrial capitalism, Kautsky asked why the

84. See for example, P. G. Lane, "Management of Estates," p. 75. 85. "Statistical Abstract," Nable 60. 86. Kar 1 Kautsky, La Question Agraire, trans. from the German by
Edgard Michaud and Camille Pollack (Paris, 1900 ). 
development of agrarian capitalism proceded at a different speed, and why its form could cohabitate with pre-capitalist social relations of production. 87 In a nutshell, he warned that capitalism "does not develop in agriculture in the simple way we thought,... its development is probably more complicated in this sector of the economy than in industry."88 Lenin echoed these sentiments when he wrote in The Development of Capitalism in Russia (1905): "It should be added that our literatire frequently contains too stereotyped an understanding of the territorial proposition that capitalism requires the free landless worker. This proposition is quite correct in indicating the major trend, but capitalism penetrates into agriculture particularly slowly and in extremely varied forms." 89 The key to questioning Marx's analysis lies at the level of the specific: there is no doubt, and certainly the Irish experience will bear it out, that the capitalist mode of production was the general trend. What is under examination here is what route that trend took, and having established that, why Marx was unable to point it out.

Kautsky stated that the intention of his study was to consider the application of Marx"s method to agriculture. "We should ask: is capital, and in what ways is capital, taking hold of agriculture, revolutionising it, smashing the old forms of production and of poverty and establishing the new forms which must succeed."90 After tracing the historical movement of capitalism into agriculture, he went on to observe that "the currents and tendencies which thwart the process of concentration in industry are active in agriculture as wel1. But in agriculture other tenciencies operate. . " 91 He observed the following: First, unlike machinery or tools, land as a means of production is limited in quantity. Its amount cannot be increased; hence, centralisation of land has an absolute end point. Second, its quality may differ according to natural conditions. These factors are inherent and not transferable, although its lesser qualities can be overcome by fertilisers or pachinery, or as with distance,

87. Editorial Note to Banaji, "Kautsky,", p. I.

88. Banaji, "Kautsky," p. 29.

89. Lenin, Development of Capitalism, $3: 178$.

90. Banaji, "Kautsky," p. 3.

91. Ibid, p. 30. 
by transportation. Third, agrarian capitalism demands the centralisation of land into larger unites; the landowner or farmer can not increase his wealth except through uniting smaller units。 92. The process of centralisation is therefore absolutely essential. This contrasts with industrial capitalism where, as Marx noted in Capital, accumulation was the "starting point."

Furthermore, availability or non-availability of labour acts as a crucial factor in promoting changes in the means of production as well as centralisation. In industry, where small firms (unless engaged in the production of luxury items) generally recede or fold in the face of large-scale competition, the lack of adequate labour reserves results in the adaptation of improved machinery. 93 In contrast, the lack of labour is "in most cases the basic cause for the retreat of large holdings before smaller ones." 94 The process is, however, not one dimensiona 1; as the "number of small cultivators proliferates on the periphery of big farms, the pool of available manpower expands, thus reinforcing the vitality and dominance of the large holding." Hence, Kautsky argues that the tendency is for an alteration between centralisation and fragmentation of agricultural units, whereby the small units provide the essential labour requirements for the capitalist farms. This tendency is conditional upon a shortage of agricultural labour, although large holdings, despite their technical superiority, can "never establish an exclusive domination in any country" under the capitalist node of production.95 Further, and more importantly, the existence of the peasantry on the fringes of capitalist society is due not to his

92. The need for the properties, that are to be centralised, to be contiguous is also important (although not necessarily Official candidly admitted that 'fully one third of the holdings already sold are still uneconomic because land for enlargement was not available." Quoted in o Gráda, "Aspects of Irish Productivity," P. 18. 93. The reverse also holds true; as James connolly noted, the
availability of cheap labour "deprived employers of the stimu-
lus of rising lus of rising costs to increase efficiency." Quoted in Lee, Modernisation, p. 11 .

94. Banaji, "Kautsky," p. 34; Lenin, Development of Capitalism,
3:178.

95. Ienin (CW 4:136) supports Kautsky stating: "Thus, within the limits of the capitalist mode of production it is impossible to count on small-scale production being entirely eliminated from agriculture, for the capitalists and agrarians themselves strive to revive it when the ruination of the peasantry has gone too far. Marx pointed to this rotation of concentration 
superiority over large-scale production but to his ability to reduce his living costs to the lowest denominator, relying upon his own and his ramily's labour power to work the land.

But, other factors may also contribute to the resilience of the small holder; domestic industry operates as a safety-valve, similar to seasonal migration. 96 Likewise, as capitalist industry extends into the traditionaliy rural regions of the country, it provides a mechanism not only for its own provision of labour (technical superiority creates redundancy in one area of production which is re-employed in another), but, as a means of employment for the farmer and/or his children, it serves as a "means to safe-guard their property against bankruptcy."97 In Ireland, remittances from emigrants, particularly from America, Australia and Britain, provided a needed source of income. 98 While labour shortages favour the expansion of medium holdings and the proliferation of small ones, once the labour problem is solved, the tendencies which aid this development "will cease to operate." gri

Once agriculture comes fully under the dominance of the capitalist mode of production, the burdens of the small farmer will multiply. The law of capitalist competition effecting the relationship of large to small holdings will begin to operate, intensifying the inefficiency and poverty of the latter. The small man will be forced to fully proletarianise himself and his family in order to survive. 100 The significant contradiction of seasonal or part-time industrial employment then comes into force; the conditions of exis-

and parcellisationof the land in capitalist society as far back as 1850 , in the Neue Rheinische Zeitung." The reference to Marx is to the following quotation from a review of "Le Socialisme et L'impot, par Emile de Giradin, Paris, 1850," in Karl Marx/Fukiderick Engels, Collected Works (London, 1978) $\mathrm{CW}$ 10:335. Therein Marx states, "And finally, if in France the tide has already begun to turn from fragmentation to concentration, in Britain the large landed estates are making giant strides towards renewed disintegration, conclusively proving that agriculturennecessarily proceeds in an incessant cycle of concentration and fragmentation of the land, as long as bourgeois conditions as a whole continue to exist." "Unfortunately this statement did not heip him to understand the
Irish case any better.

96. See Cullen, Economic History, P. 151; E. R. R. Green, The Lagan Valley, 1780-1850: A Local History of the Industrial Revolution, Studies in Irish History, vol. 3, T. W. Moody, R. D. Edwards and D. B. Quinn, eds. (London, 1949) pp. 123, 160; Maurice Dobb, Studies in the Development of Capitalism

97. Banaji, "Kautsky," p. 38. 
tence of the smali holder are revolutionised under the influence of the town and capitalist social relations of production. International competition will only further aggravate the small holders predicament, as it forces even the less efficient or miser ly larger farmer to give way. 101

The ultimate force behind this transformation is not, the awakened consciousness of the small farmer to his precarious position. If this were the case, he would have relented to economic pressures earlier, as Marx had anticipated. Instead, Kautsky concludes that the "motor force" behind this transformation is to be located in capitalist industry, which has "smashed the unity of industry, and agriculture in the country-side, that converted the peasant into the pure agriculturalist, a comodity producer tied to an unknown market, that established the possiblity of his proletarianisation."102 It was industry that revolutionarised the means of production and brought about a "qualitative" distinction between agricultural holdings that produced purely for household consumption and those that produced for the market. Whereas the early period of capitalist agriculture saw the cohabitation of capitalist and pre-capitalist modes of production, "now it is big capitalist industry that predominates and agriculture that tails behind, adapting its requirements."103

\footnotetext{
98. Sherman, "Land Purchase," p. 70.

99. Banaji, "Kautsky," p. 40.

100. See for example, Hugh Brody, Inishkillane (Harmondsworth, 1973). 101. Engels, "American Food and the Land Question," Labour Standard, July 2, 1881, MEI:317.

102. Banaji, "Kautksy," p. 46. Marx reached the same conclusions about the power of industrial capitalism in vol. 1 Capital.

103. Ibid., p. 47.
} 
From the foregoing discussion, it seems clear that Kautsky's and Lenin's revelations about capitalist penetration into agriculture bear a closer resemblance to post-famine Ireland than does that of either Marx or Engels. Nevertheless, this discussion should not be concluded without adding that Marx's examination of capitalist agriculture was most likely only a preliminary encounter. In having studied the extension of capitalism into manufacturing production, he assumed that the process entered agriculture in a smilar fashion, especially with regard to speed and efficiency. However, as Kautsky determined, counter-acting tendencies arise that not only slow that process but can appear to retard capitalist growth as well. The poverty and pre-capitalist enviroment of the small holder are alone insufficient bases for his demise; instead, numerous instances account for the small farmers: essential contribution to capitalist agriculture. In addition, the notion of ownership - whether real, fictional or prophesized - is a powerful psychological factor in encouraging his retention of land against econonic odds. The Irish experience provides a case in point.

In assessing Marx and Engels' contribution to our understanding of post-famine Ireland, we must place these critical remarks in the proper perspective. There is no doubt that insofar as they recog.. nised and called attention to the revolution in agrarian class structure their writings are dynamic. The key here is not, therefore, the general speed of that transformation, although as has been discussed that aspect holds important significance for Marx's theoretical configuration of capitalist agriculture, but rather the acknowledgement that the famine precipitated the introduction of capitalist social relations of production into Irish agriculture. In addition, by rejecting the overly-optimistic views of many of their contemporaries as well as the trenchent anti-English analysis offered by most nationalists, their analysis sought an explanation for Ireland"s underdevelopment that was based on an understanding of English capitalism and not conspiratorial politics. That is, by placing consideration of Irish agriculture in the chapter headed the General Law of Capitalist Accumulation, Marx scorned the historicist argument that focused attention on the act of Union and

English anti-Irishness, and turned to evaluate how the trans- 
ference of capital, foodstuffs, and labour from Ireland to England formed an integral and necessary part of their respective economic growth.

In the political arena, however, the implications of their miscalculations about capitalist agriculture meant that neither Marx nor Engels were prepared for the Land League phenomena. Their general strategy had held that a Fenian-led national revolution in Ireland would have profound repercussions by overthrowing the English aristocracy's stranglehold over Irish land and by prompting social revolution in England. They seemed to believe that small to medium-sized tenant-farmers, who had the most lost ander Englishdominated capitalist expansion, would suddenly take revolutionary flight. These farmers, might, they argued, see their salvation in the establishment of an independent Ireland. As such, they echoed the sentiments of Thomas Luby, Fenian, who said that "no worthwhile reform could be got from the British Parliament."104 What they did not anticipate was the tenants? eagerness to down their nationalist zeal in the face of economic gain. Hence, what neither Marx or Engels understood was the intensely petit-bourgeois orientation of the nationalist movement; ironically for them, this was most evident through its demands on the land question. This misconception is surprising given Marx's unique contribution to an understanding of French politics. Indeed, as early as 1850 in an address to the Commist League, Marx and Engels had described how the interests of the tenantry and that of commists would inevitably collide over the agrarian issue. The former would desire to implant themselves upon the land, while the latter would seek nationalisation. 105 And clearly this had occurred: Lalor, decried as a radical, argued strenuously in a mythical way, for private ownership, ${ }^{106}$ while Davitt fell strongly under the influence of Henry George who desired a land tax over direct nationalisation. ${ }^{107}$ Visions of the people

104. Quoted in T. W. Moody, "The Fenian Movement in Irish History," The Fenian Movement, Thomas Davis Lecture series (Cork, 1978)

105. "Address of the Central Authority to the League," March 1850, CW 10:284-285.

106. See Nathaniel Marlowe, ed. and intro., James Fintan Lalor Collected Writings (Dublin and London, 1918 ); Thomas OPNei11, "The Economic Ideas of James Fintan La lor," Irish Ecclesiastical Review, vol. 74 (1950) p. 402; Michael Gallagher, "Socialism and the Nationa list Tradition in Ireland, 1798$1918, "$ Eire-Ireland, vol. 1.2, no. 2 (1977) pp.63-102; C. J. 
of Ireland controlling the landof Ireland had nothing in common with Marx and Engels" view of class struggle.

A partial explanation for their peculiar position must rest with their inadequate analysis of tenants, agrarian capitalism, and land fever. Their naive classification of tenants as peasants who were almost always in a transitional move towards proletarianisation leaves much to be desired. Similarly, it is clear that their analysis of the agrarian and nationalism linkages were emotionally rather than analytically based. 108 They seen to have accepted the notion that Fenians might be capable of uniting both elements in the ultimate victory of the latter. Yet, by 1874 , Engels had already eliminated them as a viable political force in prem ference to parneli; 109 by 1888 , he had obviously lost any hope that the tenantry held any vision beyond ownership.

To some extent, then, Marx and Engels relief too heavily upon an impressionistic assessment of nationalism's appeal and approaching victory, obviously because that prognosis held the greatest opportunity for the English proletariat. Their ultimate support for Parnell appears to be a volte face. 110 It is, however, difficult to determine the dimension of their praise. There is no evidence to suggest that they thought Irish nationalism was anything more than independence oriented; there is the reference to the Fenians as "socialistic" but that can be made too much of; not even the Fenians believed it of themselves. 111 Nevertheless, they were quite genuinely shocked at the treatment dished out to the Internatonal and the Paris Commune particularly by Fenians such as Luby, o'Donovan Rossa and Mitche11. 112 The depth of their dismay suggests that

Dewey, "Celtic Agrarian Legislation and the Celtic Revival: Historicist Implications of Gladstone's Irish and Scottish Land Acts, 1870-1886," Past and Present, vol. 64, (1974)
pp. 30-70.

107. See Engels' comments to Sorge in a letter dated April 19, 1890. 108. To a very large extent, Marx and Engels had no first hand rem lation with Ireland or with Irish nationalists. While both were intensely interested in the Irish question between 1867 and 1869, and wrote of it in articles, books, and correspondence, their familiarity with specific problems of the Irish social and political formation left much to be desired. This should not detract from their remarkable insight into the revolution in class structure occurring in post-famine Ireland, of which they were almost uniquely aware. Nonetheless, politically they assumed a much more optimistic progres. sion to revolution than resulted. 
they believed Irish nationalism held either within itself or the key to social reform. This progressive element would come to the fore once independence was established. Engels ? remarks of 1888, when he referred to the land-owning desires of the tenantry, would indicate that that belief had lost its lustre. Indeed, support for Parnell and Home Rule suggests their disillusionment not only with Fenianism but with Irish nationalism as well. They were no longer adament that full independence was the solution; federalism or Home Rule - could, in fact, equally serve the designs of the English proletariat. In the last analysis, they pinned their sails to Irish nationalism only in the belief that independence and bourgeois democracy would create the essential conditions for social revolution.

109. Engels, "The English Elections," Der Volksstaat, no. 26,
March 4, 1874, MEI:311. 110. See, for example, Engels, "The Irish Struggle," Der Socialdemokrat, July 13, 1882 .

111. See Marx, "Notes," MEI:124, and "Out1ine Report," MEI:126

112. See Hazelkorn, Irish Dimension, chapt. I. 